\title{
Trade Sanctions: A Minor Hindrance or Complete Disaster
}

\author{
Johan Van Rooyen, Amrita Nath \\ Department of Business and Technology, Webster University, Cha-am, Thailand \\ Email address: \\ rooyenjv@webster.ac.th (J. V. Rooyen), nath.amrita19@gmail.com (A. Nath)
}

\section{To cite this article:}

Johan Van Rooyen, Amrita Nath. Trade Sanctions: A Minor Hindrance or Complete Disaster. International Journal of Economic Behavior and Organization. Vol. 8, No. 3, 2020, pp. 74-80. doi: 10.11648/j.ijebo.20200803.14

Received: May 14, 2019; Accepted: September 17, 2019; Published: October 26, 2020

\begin{abstract}
This paper looks into the impacts trade sanctions have on a country, in particular the economic and financial impacts. The question raised is whether trade sanctions indeed have impact of reducing the economic welfare of a country and if so to what capability? Two cases of trade sanctions have been examined: UN sanctions on Iraq and US sanctions in Iran. The analysis suggests that the despite affecting the economy of the target country, the extent to which it impacts in damaging the economic and financial resources depends upon the type and severity of the sanction. In Iraq, the complete comprehensive multilateral trade sanction crippled its economy and financial pushing it into a state of grave fiscal and humanitarian crisis. In Iran, the unilateral trade sanctions imposed by US in the form of trade barriers, has impacted by the country but economic and financial growth continues with Iran's other trading partners.
\end{abstract}

Keywords: Sanctions, Financial Impact, Iraq, Trade Barriers

\section{Introduction}

Economists and political theorists write extensively about trade sanctions ${ }^{1}$ and the role it plays in the international global economy. Despite their many flaws, sanctions have been used extensively by used by developed countries, such as the United States, Europe and international organisations such as the United Nations and the European Union. It has especially been utilised as a preferred form of foreign policy tool (see Figure 1) in $21^{\text {st }}$ century contemporary global politics. The existing literature points towards various different mechanisms on how sanctions can prove to be effective. Yet its sole purpose is quite basic- "The goal of sanctions is clear and simple: to impose a reduction in economic welfare on the target country and thereby reduce its willingness to persist in antagonising the world community" [1]. In the post-Cold War era more than 500 sanctions [2] have been issued in the world in an effort for Western powers to stress their influence without resorting to violence. Sanctions have been asserted for a wide range of goals from nuclear non-proliferation, countering terrorism, battling drug trafficking to altering policy changes, fighting against humanitarian violence etc.

1 For the purpose of this paper: economic sanctions, embargoes, boycotts will be considered synonyms for trade sanctions.
Do trade sanctions actually reduce economic welfare of a country? And if so, in what capacity? In order to find the solution to these answers, this paper will look into two different cases of trade sanctions issued by two different kinds of international actors. For the first case, we examine the impact of United Nations trade sanctions on Iraq during the 1990s after the Gulf War. And for the second case, we look into United States re-imposing trade sanctions on Iran in 2018.

\section{What are Trade Sanctions?}

Trade sanctions can be defined as means through which a particular country (the initiator) legally and publically attempts to force changes with another country (the target) by reducing their economic welfare [1,3]. Trade sanctions can either be unilateral meaning one initiator imposing on one target country or it can be multilateral, multiple initiators (countries) serving trade ties with numerous target countries. It can take the form of trade barriers, tariffs or financial restrictions.

\section{Literature Review}

Sanctions are a ubiquitous and effective foreign policy tool to initiate change. Afesorgbor and Mahadevan (2016) in their work have compiled the essence of sanctions. They write it is a weapon used against a target country issuing maximum 
economic damage in order to pressurise the target state to change its policies in tangent with the sender state [4]. In order to understand the effectiveness of trade sanctions, Bapat and Morgan (2009) conducted an empirical study comparing unilateral against multilateral trade sanctions. They conclude that multilateral trade sanctions are less or no more effective than unilateral sanctions. The authors elucidate that due to problems faced with public goods and the ability of specific targets to manipulate coalitions, multilateral sanctions can be assumed to fail despite having the potential of imposing a much greater level of cost on the target state [5]. Yet, Marinov (2005) believes that economic sanctions have little to absolutely no effectiveness other than perhaps destabilising the mind of leaders. After assessing numerous cases, such as Iraq, Cuba, North Korea, Haiti, the author concludes that economic sanctions are more a tool for assessing the leadership style of the target state [6]. Peksen and Son (2015), Dizaji and Van Bergeijk (2013) and Afesorgbor and Mahadevan (2016) have analysed in their works, approach the topic of economic sanctions from a more domestic aspect. They inspect the economic outcomes of sanctions on GDP, currency, trade, government consumption and employment rates of the target state [7, 8, 4]. Afesorgbor and Mahadevan (2016) particularly focus on the impact of economic sanctions in the redistribution of income within society of the target state. Hufbauer et al (2007) explain in their book that when it comes to sanctioning a state different instruments of sanctions can be employed against the target state. Moreover, the economic and political impact of different types of sanctions differ greatly from one another [9].

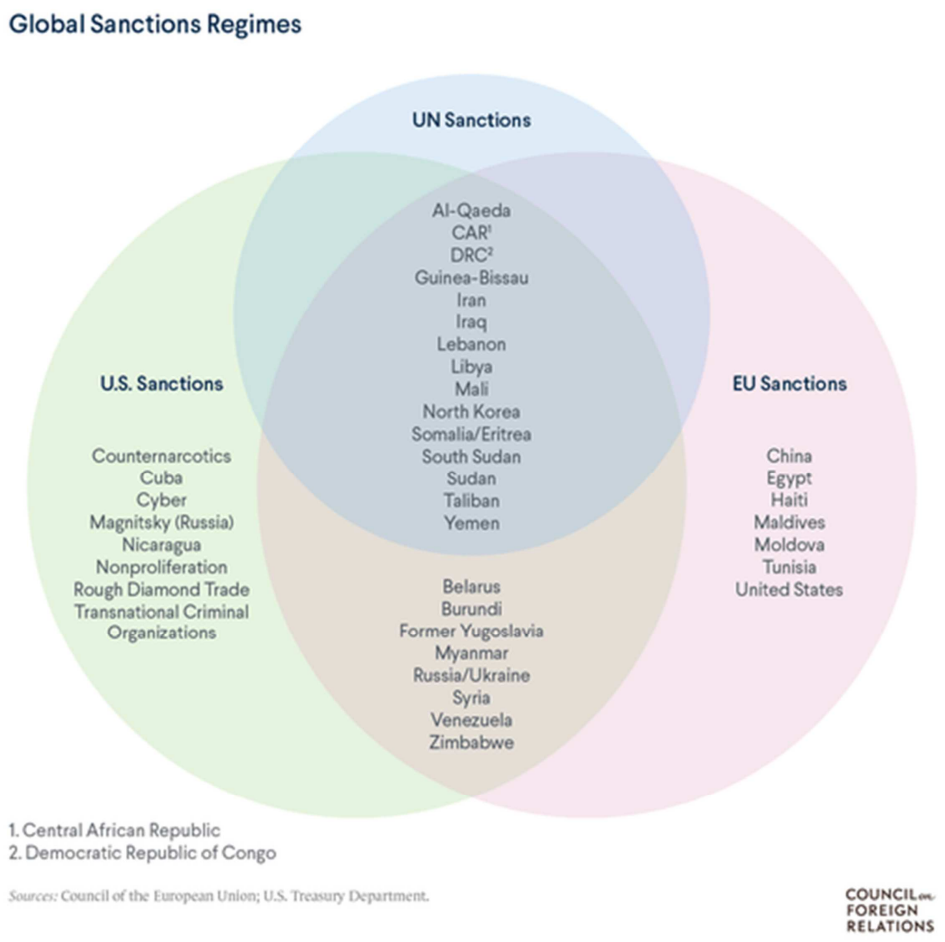

Figure 1. Western \& UN Sanctions in the world.

\section{Analysis}

\subsection{UN Sanctions}

Article 41 in the UN Charter allows for the measure of sanctions as means of enforcement without the involvement of armed forces. When the UNSC decides that a target country stands as a threat towards international peace and security, it can impose a trade or economic sanction, wherein all member states either partially or completely disrupt economic relations [10]. After being adopted by the UNSC, all member states of the UN are obligated to adopt the trade sanction against the target. Figure 2, shows the effectiveness of various UN sanctions.

Data gathered by (Neuenkirch \& Neumeier, 2015) analyses the impact of economic sanctions on 67 countries over the time period of 1976-2012. After conducting a comprehensive and in-depth research on the impact of UN sanctions, (Neuenkirch \& Neumeier, 2015) suggest that the UN sanctions affect the target country's economic growth by an average of more than 2 percentage points (pp) decline in real per capita GDP growth rate [11]. Comprehensive trade sanctions exert their influence on a target country for an estimated 10 years affecting the GDP growth. This results in a huge economic cost for the country.

Iraq

UN sanctions enforced on Iraq, were of the most extreme multilateral comprehensive economic sanctions to be imposed on a country. Resolution 661 (1990) banned all exports to and from Iraq expect for products strictly for medical use and in some cases, food items. Following the Gulf War, resolution 687 (1991) a similar set of strict 
economic sanctions were imposed but with the authorisation of petroleum and petroleum exports, in order for Iraq to be able to pay for their medical, food and civilian supply imports. These sanctions brought about economic and financial crisis in Iraq. (Al-Roubaie \& Elali, 1995) in their work mention that since Iraq had a weak economic structure that depended heavily on trade, it made economic recovery even more difficult for the country [12]. The Iraqi government launched a report during that time to show it lost US\$18 billion in income between August 1990 and January 1991 [13]. Figure 3 shows the damage the Iraqi government bore after the sanctions were imposed.

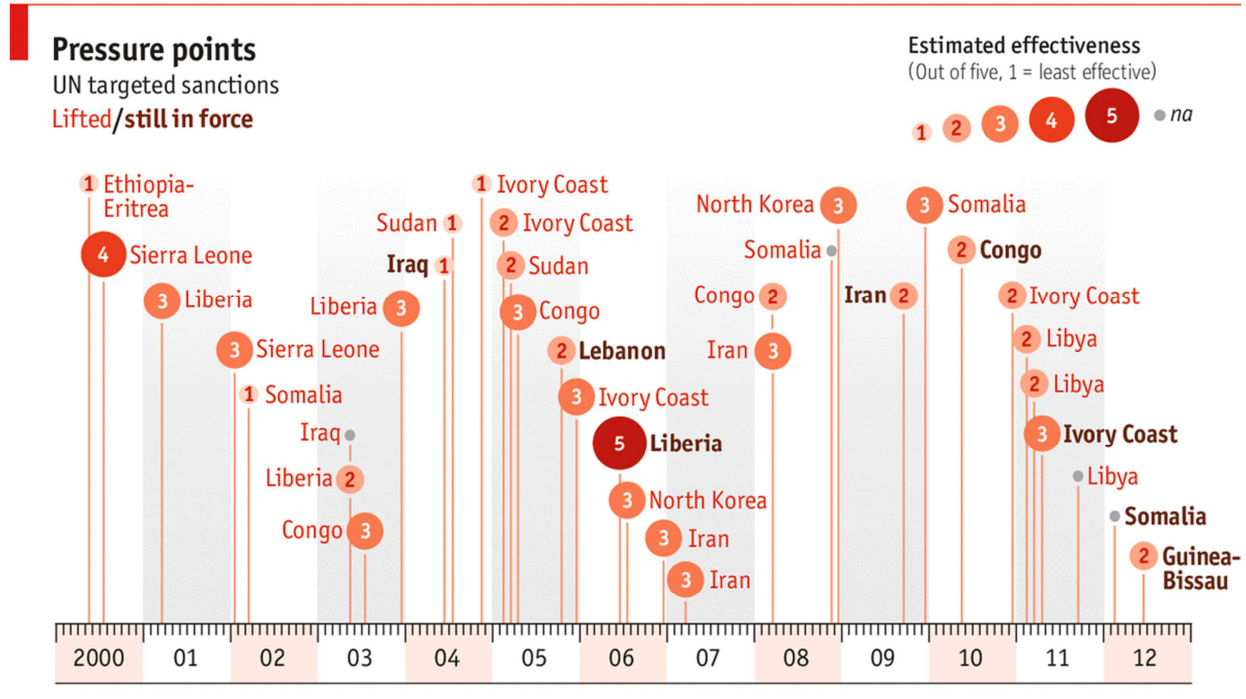

Source: UN Targeted Sanctions Project at the Graduate Institute, Geneva; The Economist

Source: The Economist; Geneva.

Figure 2. UN Targeted Sanctions Project.

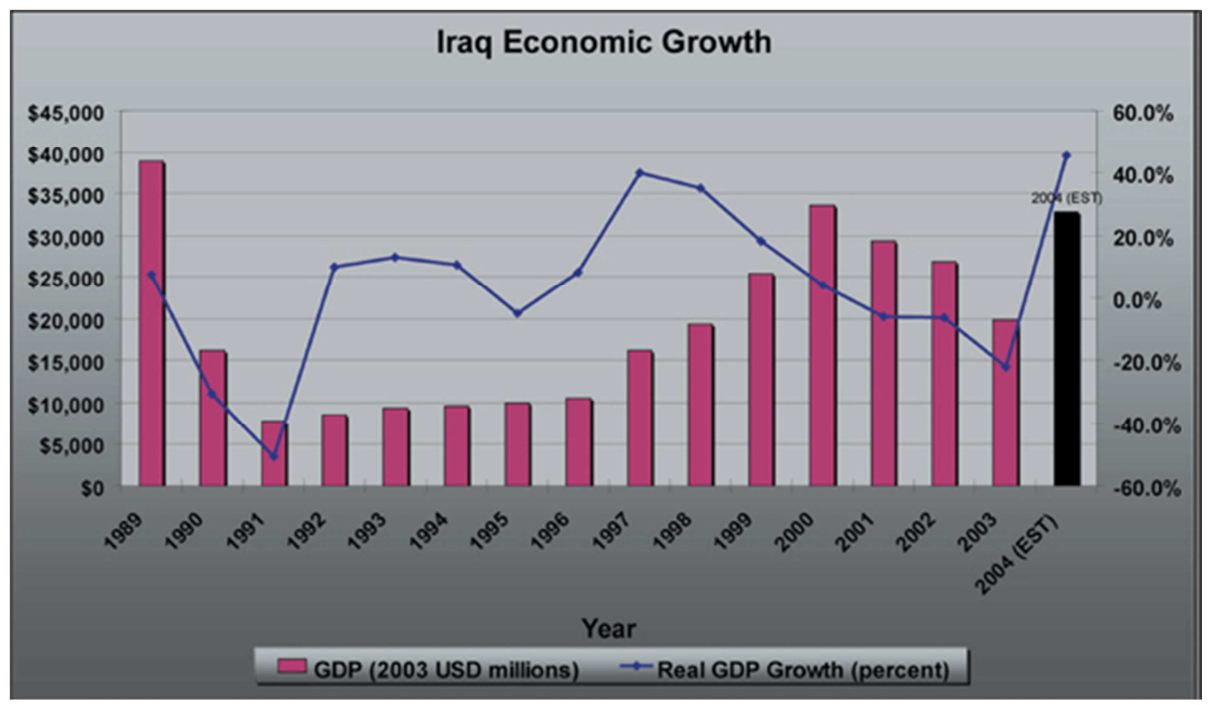

Source: Central Intelligence Agency (CIA).

Figure 3. Iraq GDP Timeline.

The government's revenue sources were seriously depleted and the value of the Iraqi Dinar dramatically dropped. The impact on income levels was also disastrous. The first year after the imposition of the sanctions saw a decline in real earnings to $90 \%$ and following years between 1991-1996 it fell by $40 \%$ [14].

Table 1. Socio-Economic effects on Iraq after sanctions. Source: Shah, A. (2005). Global Issues.

\begin{tabular}{lll}
\hline Dinar Effects (Immediate) & Short Term Effects (Intermediate) & Long Term Effects (Chronic) \\
\hline Decreased Imports & Health & Health \\
Medicines & Deterioration in health status and health services & Reduction in general health status \\
Food & Increased: Morbidity and Mortality & $\begin{array}{l}\text { Deterioration in health services and national capacity for } \\
\text { healthcare }\end{array}$ \\
\hline
\end{tabular}




\begin{tabular}{lll}
\hline Dinar Effects (Immediate) & Short Term Effects (Intermediate) & Long Term Effects (Chronic) \\
\hline \multirow{2}{*}{ Agricultural Inputs } & Low birth-weight babies, infectious diseases, & Resurgence of illness and disease associated poverty \\
Water/Purification/Supply Inputs & Detemics, malnutrition & Loss of previous gains in preventive and curative care services \\
Decreased Exports & Food Security & 2. Economic \\
Impact on export earnings, access to & Higher market prices for basic food stuff & Decline in revenue from all sources \\
foreign currency, etc. & Shortages on basic food items & Decline in GDP, GNP, per capita income \\
& Decrease in average caloric intake & Loss of trade partners, regional/international trade interests \\
& Decrease in agricultural and livestock production & Chronically high unemployment \\
& Black Market Purchases & Collapse of public and private infrastructure \\
& 3. Economics & 3. Social \\
& Decreased export earnings & Increase in poverty \\
& Closing down of businesses and industries & Increase in social inequality (income gap) \\
& Inflation & Decrease in social cohesion \\
& Increase in personal/household loans & Social upheaval, violence distress \\
\hline
\end{tabular}

The above Table 1 maps out all the socio-economic effects that were felt by the sanctions on the Iraqi civilian population. The frightening cases of poverty, malnutrition (see Figure 5), mortality rates and unemployment were severe causes of the constraint the society underwent as a result of fiscal crisis due to the impact of lower oil revenues.
As the government began to print more bills of money in order to be able to finance expenditures, it ended up causing chronic high inflation in the country [14]. Figure 4 below highlights the debt Iraq owed to the international community in comparison to their GDP.

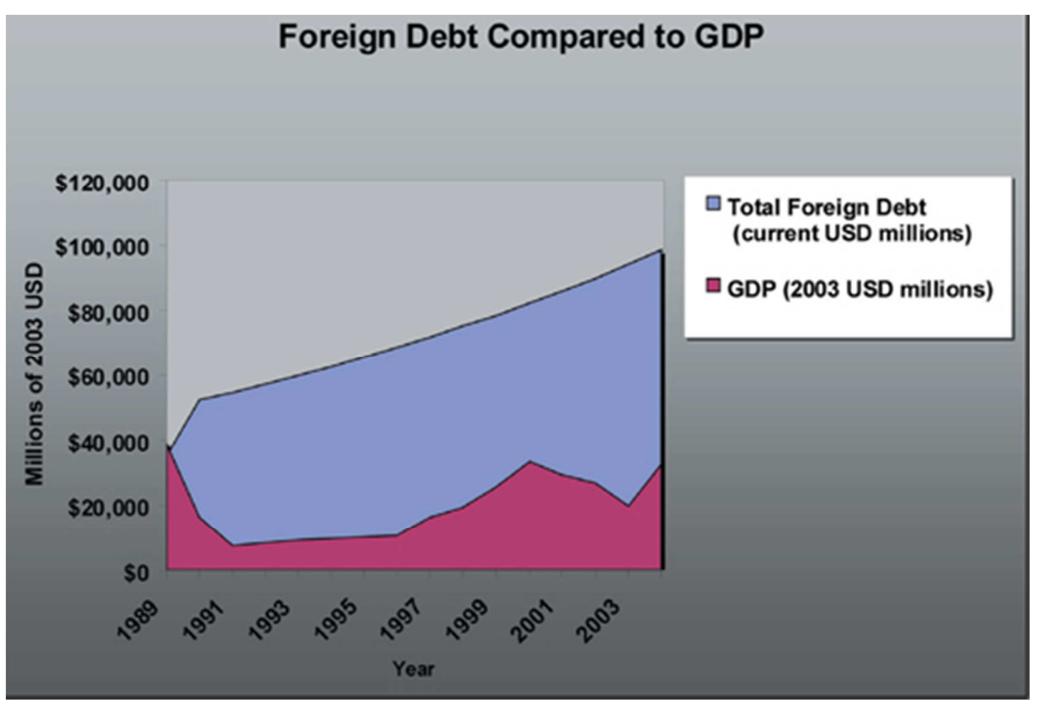

Source: Central Intelligence Agency (CIA).

Figure 4. Iraq foreign debt to GDP (1989-2003).

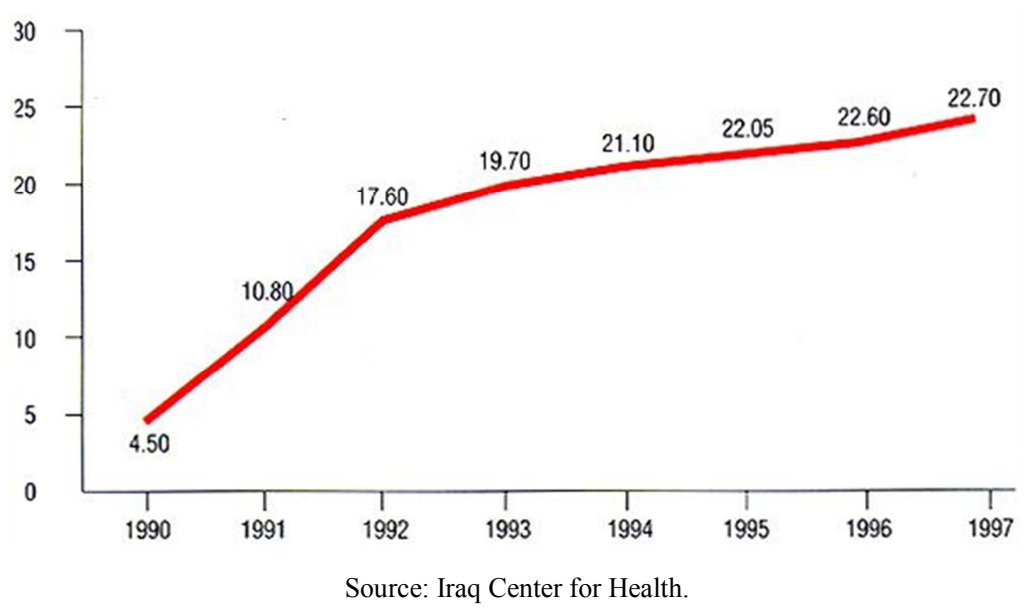

Figure 5. Children born underweight. 


\subsection{United States Sanctions}

Iran

After withdrawing from the Joint Comprehensive Plan of Action (JCPOA), United States has completely re-imposed US sanctions on Iran in 2018 that had been waived under the JCPOA. The sanctions cited restrictions on purchase of the USD, trade in gold and other precious metals, sale to Iran of automotive, its parts and services. Furthermore, Iran faced curbs on their sale of petroleum and petroleum products. Iran immediately felt the impacts. Their economy saw a decline in oil-production and GDP growth. The Iranian Rial started weakening and inflation seemed to be rising [15]. Infact the last months of 2018, saw Iran plunge into a form of deep recession [16]. The IMF noted that the economy's real GDP will fall by $1.5 \%$ in 2018 and another $3.6 \%$ by the end of 2019 (International Monetary Fund, 2018). Oil exports have declined and unemployment is on the rise. Unofficial unemployment rate is said to have reached $27 \%$ among the working-youth population in Iran [16].

\section{Iran's oil output}

\section{Production in millions of barrels per day}

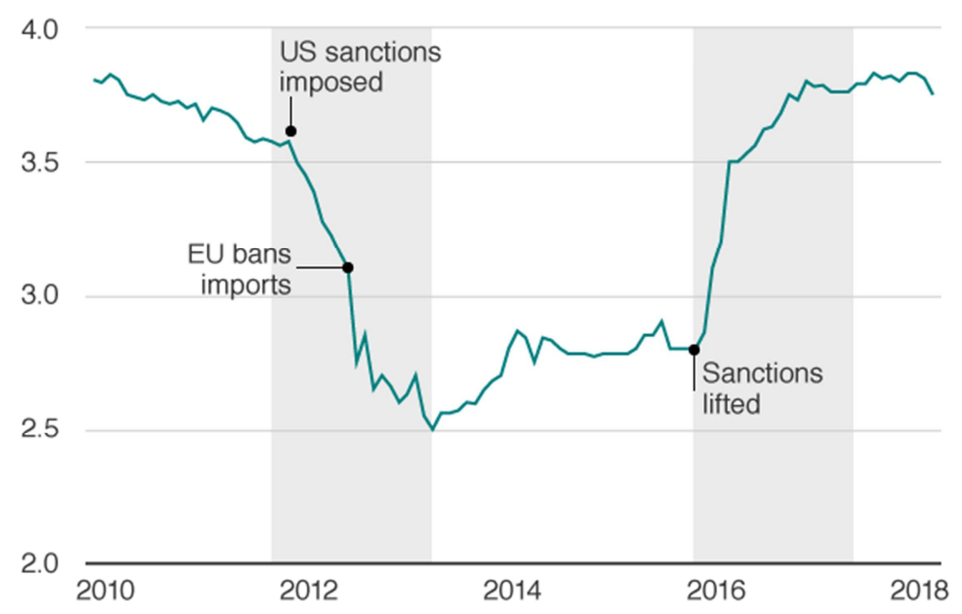

Source: Central Bank of the Islamic Republic of Iran, ITABXOIL index.

Figure 6. Iran Oil Exports.

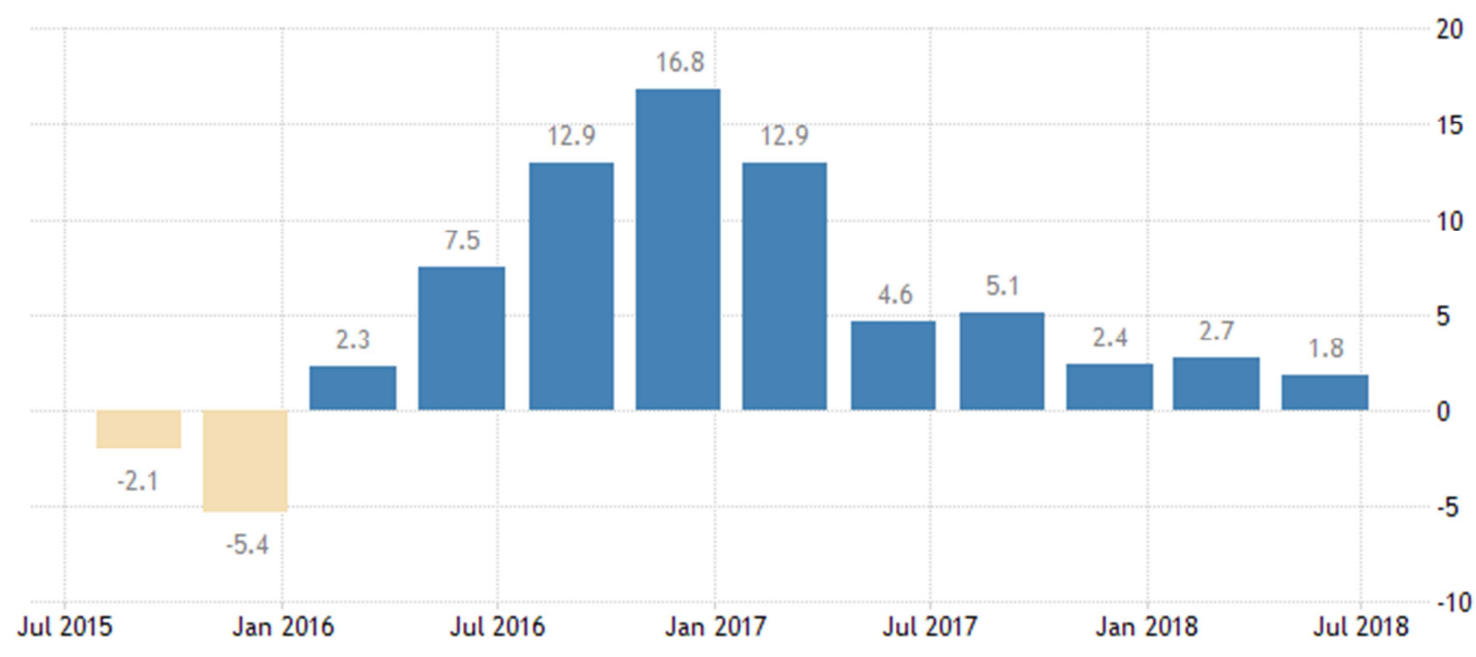

Source: Trading Economics. Central Bank of Iran.

Figure 7. GDP growth of Iran 2015-2018.

Iran still has the option of relying on its other trading partners - UK, France, China, Russia and Germany (other members of the JCPOA agreement) have ensured their commitment to the deal. The EU has launched a "blocking statute" as a counter measure against US re-imposing sanctions. Moreover, JCPOA parties have contracted together to the creation of a special purpose vehicle (SPV) to conduct trade with Iran and avoid sanctions [15]. Albeit US unilateral sanctions have a strong impact in causing economic damage to Iran, it also renders the opportunity for Iran to develop 
stronger ties with other trading partners. The EU, India and China are all exploring alternate ways of paying through independent financial tools shunning the US dollar and becoming victims of US sanctions [15]. Figure 4 and Figure 5 shows us the trading relations Iran has with other countries for oil and non-oil exports.

\section{Iran's biggest customers} Average exports in thousands of barrels per day from
November 2017 to April 2018

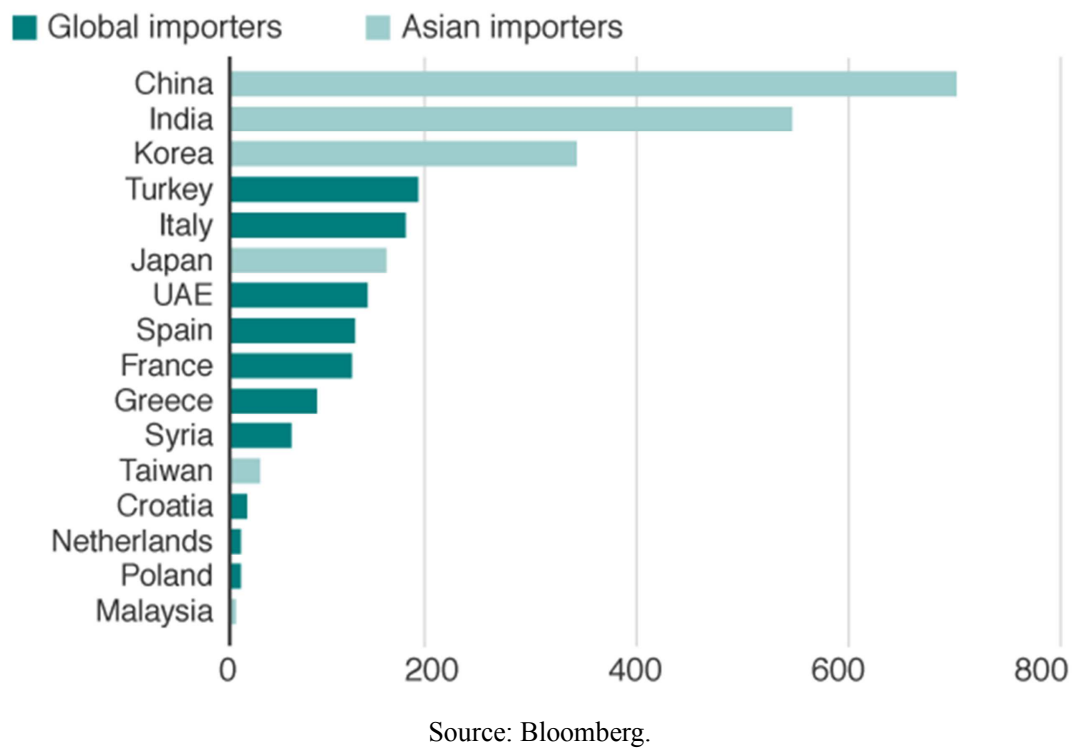

Figure 8. Iranian Exports for Oil.

\section{Iran exports: Top five destinations for non-oil products}

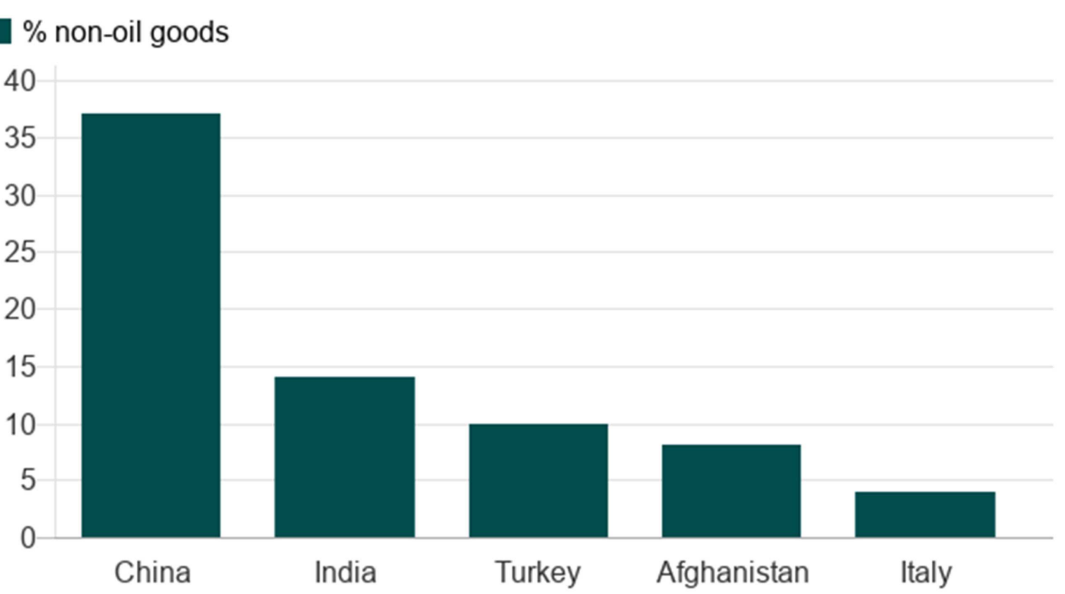

Figure 9. Iranian Exports for Non-Oil Products.

\section{Conclusion}

The effects of trade sanctions placed on a country can vary from situation to situation. Trade sanctions can serve as a hindrance, but it still creates the opportunity for new methods of trade and financial and economic growth. Such as the 2018 US sanctions on Iran. Although, Iran's economy did show signs of slowing, trade in petroleum and petroleum products with its other trading partners show signs of developing to further heights. Moreover, Iran's trading partners are agreeable to devise new financial tools to avoid implications of the US sanctions and continue trade uninterrupted, thereby developing their economic and financial capabilities. Yet, at the same time we trade sanctions can also have devastating effects on a country, crippling their economic and financial resources, such as the 1990s UN sanctions on Iraq. For the nature of those sanctions, we witnessed the impact trade sanctions can have on damaging the GDP, fiscal resources and the civil population of a country. The poor in Iraq had felt the full effects on the sanctions based on their unemployment rates, mortality, malnourishment and lack of health services.

But what the analysis did reveal to us was that the economic and financial impact of trade sanctions depends 
upon the type and severity of sanction placed.

Severity (Trade Barriers or Embargo) - Depending upon whether it is a complete, comprehensive embargo or trade barriers the implications of damage and capability to cope depend. An embargo is the severest form of sanction as it calls for a complete ban on trade and commerce with the target county. Thus, such a kind of sanction will deteriorate the economic and fiscal state of affairs to a great extent for the target country. For instance, the UN embargo towards Iraq in 1990 after the Gulf War.

Type (Unilateral or Multilateral) - a unilateral trade sanction is relatively combatable, as the target country can find alternate methods or trading partners to make up for the deficiencies in trade and commerce. However, a multilateral sanction makes things a little more complicated as it involves a group of initiator countries that target a country. This is the reason why UN issued trade sanctions have a higher impact than unilateral sanctions.

In conclusion, the economic and financial impacts depend upon the type and severity of trade sanctions. Thus, no trade sanction has the same impacts as previous sanctions and it heavily varies from one situation to another.

\section{References}

[1] Porter, R. C. (1979). International Trade and Investment Sanctions: Potential Impact on the South African Economy. The Journal of Conflict Resolutions, 23 (No. 4), 579-612.

[2] Cashen, E. (2017). The Impact of Economic Sanctions. World Finance. Retrieved from: https://www.worldfinance.com/special-reports/the-impact-ofeconomic-sanctions.

[3] Lindsay, J. M. (1986). Sanctions as Policy Instruments: A ReExaminaiton. International Studies Quaterly, 30 (No. 2), 153173.

[4] Afesorgbor, S. K., \& Mahadevan, R. (2016). The Impact of Economic Sanctions on Income of Target States. World Development, Vol 83, pp. 1-11. Retrieved from: https://doi.org/10.1016/j.worlddev.2016.03.015.
[5] Bapat, N. A., \& Clifton Morgan, T. (2009). Multilateral Versus Unilateral Sanctions Reconsidered: A Test Using New Data. International Studies Quarterly, 53 (4), 1075-1094. DOI: 10.1111/j.1468-2478.2009.00569.x.

[6] Marinov, N. (2005). Do Economic Sanctions Destabilize Country Leaders? American Journal of Political Science, 49 (3), 564-576. DOI: 10.1111/j.1540-5907.2005.00142.x.

[7] Peksen, D., \& Son, B. (2015). Economic Coercion and Currency Crisis in Target Countries. Journal of Peace Research, Vol 52, Issue 4. DOI: 10.1177/0022343314563636.

[8] Dizaji, S. F., \& Van Bergeijk, P. A. (2013). Potential Early Phase Success and Ultimate Failure of Economic Sanctions: A VAR Approach with an application for Iran. Journal of Peach Research, Vol 50, Issue 6. DOI: 10.1177/0022343313485487.

[9] Hufbauer, Gary Clyde \& ProQuest (Firm) (2007). Economic sanctions reconsidered (3rd ed., Expanded ed). Peterson Institute for International Economics, Washington, DC.

[10] Vreeland, J. R., \& Dreher, A. (2014). The Political Economy of the United Nations Security Council: Money and Influence. London: Cambridge University Press.

[11] Neuenkirch, M., \& Neumeier, F. (2015). The Impact of UN and US Economic Sanctions on GDP Growth. European Journal of Political Economy, 110-125.

[12] Al-Roubaie, A., \& Elali, W. (1995). The Financial Implications of Economic Sanctions Against Iraq. Pluto Journals, 17 (3), 53-68.

[13] Middle East Economist Digest, 30 August 1991, 22.

[14] Boone, P., Gazdar, H., \& Hussain, A. (1997). Sanctions Against Iraq: Cost of Failure. Center for Economic and Social Rights.

[15] Segal, S. (2018, November 5). The Economic Impact of Iran Sanctions. Retrieved from Center for Strategic International Studies: https://www.csis.org/analysis/economic-impact-iransanctions.

[16] Alavi, A. (2019). Iran's Official Figures Indicate Alarming Unemployment Rate Later This Year. Radio Farda. Retrieved from: https:/en.radiofarda.com/a/iran-official-figuresalarming-unemployment-2019/29698225.html. 